\title{
Lethal management may hinder population recovery in Iberian wolves
}

https://doi.org/10.1007/s10531-018-1668-x

Mario Quevedo ${ }^{1}$, Jorge Echegaray ${ }^{2}$, Alberto Fernández-Gil ${ }^{3}$, Jennifer A. Leonard ${ }^{2}$, Javier Naves $^{3}$, Andrés $^{3}$ Ordiz $^{4}$, Eloy Revilla ${ }^{3}$, Carles Vilà ${ }^{2}$

${ }^{1}$ Dpt. Biología de Organismos y Sistemas, and Research Unit of Biodiversity (UMIB, UO-CSIC-PA), Universidad de Oviedo, 33006 Oviedo, Spain. Email: quevedomario@uniovi.es.

${ }^{2}$ Conservation and Evolutionary Genetics Group. Department of Integrative Ecology. Estación Biológica de Doñana (EBD-CSIC), Avd. Americo Vespucio 26, 41092 Seville, Spain

${ }^{3}$ Departament of Conservation Biology. Estación Biológica de Doñana (EBD-CSIC), Avd. Americo Vespucio 26, 41092 Seville, Spain

${ }^{4}$ Faculty of Environmental Sciences and Natural Resource Management, Norwegian University of Life Sciences, Postbox 5003, NO-1432 Ås, Norway

\section{Acknowledgments}

2 This study was partially supported by the Spanish Agencia Estatal de Investigación from the Ministry of

3 Economy, Industry and Competitiveness (project CGL2017-83045-R AEI/FEDER UE, co-financed with

4 FEDER). Thanks to those managers from the Spanish regional administrations that answered our

5 information requests. Fernando Jubete, Rubén Portas and Juan Ángel de la Torre helped us compiling and

6 interpreting lethal management data. 


\section{Abstract}

8 In previous centuries, wolves were extirpated across much of their range worldwide, but they started to

9 recover in Europe since the end of last century. A general pattern of this recovery is the expansion of the range occupied by local populations. The Iberian wolf population, shared by Portugal and Spain, reached its

11 lowest extent and abundance around the middle of the 20th century. Unlike other populations in Europe, its range recovery and pack counts seem to have stalled since the first Spanish country-wide census of 198688. The population shows low effective population size and remains isolated from other European wolves. This is unexpected given the protection offered by European legislation, i.e., the Habitats Directive, and the apparent availability of habitat outside its present range. We compiled records of wolves killed legally in Spain, reviewed the legislative and management framework for the Iberian wolf population, and discussed potential implications of a policy of lethal management for the ecology, genetics and conservation status of wolves in the Iberian Peninsula. Wolves are strictly protected in Portugal. Meanwhile, they are subject to culling and hunting in Spain. No wolf was legally removed by culling or hunting during the study period in Portugal, whereas 623 wolves were legally killed in Spain between 2008 and 2013. Twenty-nine of those wolves were killed in areas under strict protection according to European legislation. Despite the transboundary nature of this wolf population, we are not aware of coordinated conservation plans. Management is further fragmented at the sub-national level in Spain, both due to the authority of Spanish autonomous regions over their wildlife, and because wolves were listed in multiple annexes of the Habitats Directive. Fragmentation of management was apparent in the uneven adherence to the obligations of the Habitats Directive among Spanish regions. A similar situation is found for other large predator populations in Europe. We suggest that lethal management as carried out in Spain is a hindrance to transit and settlement of wolves, both within and beyond the Iberian wolf population. Reducing the pressure of lethal management appears a feasible policy change to improve the conservation status of the population and foster transboundary connectivity.

\section{Keywords} recovery; transboundary populations. 


\section{Introduction}

The key role of large carnivores in the functioning of ecosystems has been demonstrated in a variety of environments (Estes et al. 2011). Grey wolves (Canis lupus) are particularly important apex predators because of their large natural distribution across the entire Holarctic, and the ability of wolf packs to take down large prey (Mech and Peterson 2003; Wallach et al. 2015). Given their importance in the functioning of ecosystems, several international agreements rule their conservation and management. At the European level, those include the Convention on the Conservation of European Wildlife and Natural Habitats (the Bern Convention; Council of Europe 1979), and the Habitats Directive (European Union 1992).

Awareness of their ecological role is relatively recent. Historically, wolves were extirpated in much of their range, mostly during the last few centuries (Breitenmoser 1998; Leonard 2014). More recently, changes in economic drivers and human land uses have had a generally positive impact on wolf conservation status. Despite the historical persecution that has deeply altered the genetic structure and long-term viability of European wolf populations (Hindrikson et al. 2017), wolves have recolonized in the last decades some of their lost range, both in North America (Leonard et al. 2005) and in Europe (Chapron et al. 2014a; Gippoliti et al. 2018). Recolonization has been documented in Italy, Switzerland, and France (Galaverni et al. 2016). The eastern wolf population in the southern Baltic and Carpathians has expanded into Poland, spreading to Denmark through Germany (Wagner et al. 2012; Andersen et al. 2015). The northern population in Russia and Finland triggered the recovery in Scandinavia (Vilà et al. 2003). This overall positive trend led the IUCN to change the listing of wolves from Vulnerable in 1994 to Lower Risk in 1996 and to Least Concern in 2008.

Meanwhile, the Iberian wolf population shared by Portugal and Spain has not shown an analogous recovery from past bottlenecks. In Portugal, which nowadays includes approximately $16 \%$ of the range of the Iberian wolf population (Chapron et al. 2014b), wolves declined through the 20th century in both range and numbers (Petrucci-Fonseca 1990; Kaczensky et al. 2012; Torres and Fonseca 2016). The Spanish wolf population reached its lowest point ca. 1970s (Deinet et al. 2013) from a widespread presence in the second half of the $19^{\text {th }}$ century (Rico and Torrente 2000). From its nadir, and probably in association with changes in its legal status, the population started to recover, extending their range in northwest Spain. In 1986-1988, 294 packs were estimated in Spain in the first country-wide census, occupying about $100,000 \mathrm{~km}^{2}$, 'mostly in the northwestern quarter (Blanco et al. 1992). The second country-wide Spanish census tallied 297 packs between 2012 and 2014 (MAGRAMA 2016), largely in the same NW area of the first census. Between those 
census, other estimates mentioned 250 to 263 packs (Palomo et al. 2007; Blanco and Cortés 2012), although these are not methodologically comparable to the country-wide censuses. The 2012-2014 census found comparatively more wolf packs in the northern parts of the range, but did not find packs in Sierra Morena (Fig. 1A), from where wolves had been reported in a small detached nucleus following the rapid contraction of their range in the first three quarters of the 20th century (Padial et al. 2000; Rico and Torrente 2000; López-Bao et al. 2015). Besides the Spanish survey, wolves dispersing from the Alpine-Italian population (Valière et al. 2003; Fabbri et al. 2007; Louvrier et al. 2017) have also been detected in the eastern Pyrenees about $350 \mathrm{~km}$ east of the present range of the Iberian wolf population, although reproduction has not been confirmed.

In the light of the recovery of some European wolf populations, the relative stability in the current range in the Iberian Peninsula is striking because they are under the same international, protective legislation. The details of such protection, however, vary substantially among signatory countries and even within them (Trouwborst 2014a). Species of community interest in the Habitats Directive are listed in different annexes, which confer varying degrees of protection, and varying levels of commitment from signatory states. Wolves in Portugal are included in Annex II of the Habitats Directive as 'species of community interest whose conservation requires the designation of special areas of conservation', and in Annex IV as 'animal and plant species of community interest in need of strict protection'. In contrast, in Spain the Habitats Directive established the Douro River as the boundary for different schemes of protection (Fig. 1A). North of the Douro River wolves are in Annex $V$ of the Habitats Directive, as 'species of community interests whose taking in the wild and exploitation may be subject to management measures'. Wolves in the Spanish territories located south of River Douro are in the same annexes II and IV as in Portugal (Fig. 1A). However, if they roam east outside the southward projection of River Douro, they enter a legal vacuum (Fig. 1A; Trouwborst 2014a). In addition, wolves in territories under Annex II and IV in Spain can be killed as exceptions to the Habitats Directive.

Here we review the legal status and, where applicable, the policy of lethal management of the Iberian wolf population across the different regions in the Iberian Peninsula. We compiled official numbers on wolf culling and hunting from 2008-2013, the period for which we could gather consistent data from the various autonomous regions in Spain that used lethal management. Records of killed wolves usually included date and county or municipality; further information on age, sex, condition of the individuals, or finer scale location, were generally not available. Since wolf hunting in Spain is used as a management tool, we merged 
data on culling and hunting as overall lethal management. Both were indiscriminate with respect to age, sex, or the involvement of individual wolves in livestock damages. Below we discuss the potential implications of lethal management on the Iberian wolf population, particularly those related to its effective conservation status.

\section{Legislative framework and management plans}

In Portugal wolves were strictly protected at the national level ('Lei 88/90 Proteçao do lobo ibérico') before the release of EU's Habitats Directive in 1992. The legal text is unambiguous, targeting the recovery of the population and its natural prey base, and improving the social acceptance of the species. In exceptional cases, individual wolves could be removed by government officials; those exceptions were to be checked against the Bern Convention, so that 'there is no other satisfactory solution and that the exception will not be detrimental to the survival of the population concerned' (article 9). Later, article 16 of the Habitats Directive included similar exceptions. More recently, a decree developed the previous law ('Decreto-Lei 54/2016'), established provisions for the management of compensatory payments of livestock depredations, and mandated the development of an action plan. The latter was recently published ('Despacho 9727/2017') and referred explicitly to the maintenance of a favorable conservation status, and the need for coordination of policy with Spain. The Portuguese action plan mentions illegal persecution and other human causes of mortality among the threats for the wolf population.

In Spain, the transposition of European directives is the responsibility of the national government, while the actual management of biodiversity, including wolves, is the responsibility of the regional governments (Table 1). Spain implemented the Habitats Directive through a national law ('Ley 42 / 2007') that set the Douro River as the boundary between two management zones. The law also created a national list of protected species, but unlike the transposition of annexes of the Habitats Directive, wolves were included in that list referring only to the regions of Andalucía, Extremadura and Castilla-La Mancha, all located south of the Douro River. The legal and management frameworks became more complex because several Spanish regions include several provinces, which also have some degree of management authority. In addition, the territory of some Spanish provinces spans the Douro River management boundary (Figure 1A). For instance, Zamora harbors about 45 wolf packs, some shared with Portugal, and is divided by Douro River into a 'management side' under annex $\mathrm{V}$ of the Habitats Directive, and a 'strict protection' side under annexes II and IV (Table 1). 
Most wolves in Spain are in three neighboring regions: Galicia, Castilla y Leon, and Asturias; the first two share boundaries and wolf packs with Portugal (Figure 1A). Each one has its own management plan (Table 1); all three stressed the ecological and cultural importance of wolves, and all three listed extensive livestock practices and the social conflict related to them as the main reasons to include lethal management provisions. Galicia and Castilla y León acknowledged in their plans that they share wolves with Portugal, although only the latter suggested connectivity as a goal. Beyond that, plans are quite different in objectives and implementation. Ensuring population viability is explicit in the Galician management plan, whereas in Asturias the wording of the plan emphasizes extensive livestock practices and predator tolerance in rural areas. Castilla y León and Galicia considered wolves as a game species. Castilla y León explicitly set quotas of annual exploitation that varied from $5 \%$ to $28 \%$, and planned counting wolf packs every 10 years. Wolf hunting quotas in Galicia were assigned in response to depredations on livestock, and the plan established management zoning that included hunting in some zones, culling in response to specific livestock depredation events in others, and zones with no lethal management at all. The Galician plan mentioned that illegal human actions accounted for at least $20 \%$ of wolf mortality in the territory. Asturias did not consider wolves as game species but stated the need to control the population. It planned annual culling quotas based on wolf abundance, complaints on livestock depredations, and social conflict. However, counts of packs were the only available annual metric of wolf abundance, and there were no formal descriptions or measures of that social conflict (Fernández-Gil et al. 2016). Interpreting the legal language of these management plans is not straightforward, but, in practice, lethal management is much less intense in Galicia than in Castilla y León and Asturias (Table 1).

Several Spanish regions lack management, recovery or conservation plans for wolves in their territories. For example, Cantabria and La Rioja, in annex $\vee$ of the Habitats Directive, have relatively high culling and hunting pressure but no plans (Table 1). In contrast, a province in the Basque Country where wolves are barely present (Araba, Table 1), has its own plan, including the goal of culling wolves to restrain them. The lack of recovery plans is striking in regions under annexes II and IV of the Habitats Directive (Fig. 1A; Table 1), despite the recognized unfavorable conservation status. For instance, wolves are listed as severely endangered ('en peligro de extinción') in regional lists of Castilla la Mancha, Extremadura and Andalucia, but these regions lack recovery plans (Table 1). Furthermore, in Murcia, southeast Spain, wolves are classified as extinct, but no recovery plans were implemented. We would have expected to find plans for the regions including the Pyrenees, which occasionally receive wolves from France (Valière et al. 2003; Louvrier et al. 
2017), bringing an opportunity for the recovery of the once lost genetic flow between southern European wolf populations (e.g. Hindrikson et al. 2017). However, Catalonia, Aragón and Navarra (see Figure 1A) lack published action or recovery plans.

\section{Management-related mortality}

No wolf was legally removed by culling or hunting during the study period in Portugal. Conversely, lethal management programs took place yearly in most Spanish regions where wolves were present (Fig. 1A; Table 1). The lethal management in the period represented an overview of management schemes, though not so much the exploitation intensity of the various regions, which may show discrete blanks and spikes. For instance, 109 wolves were legally killed in Castilla and León in 2017. The relative intensity of lethal management varied among regions, and among provinces within those regions; several provinces clearly stood out (Table 1). Particularly noticeable was wolf culling in Ávila and Salamanca provinces, both south of Douro River and thus under annexes II and IV of the Habitats Directive, where wolves have a very limited distribution. North of that management boundary, the province of Zamora and regions Cantabria and Asturias showed the highest intensity of lethal management relative to wolf range (Table 1), regardless of their different consideration of wolves as game or non-game species. Lethal management was carried out even in management units with only one wolf pack in recent years (Table 1), and in regions outside the present, contiguous range of the species (Fig. 1).

At least 623 wolves were culled or hunted in six Spanish regions during 2008-2013 (Table 1; Fig. 1). Most (594 wolves) were killed north of the Douro River (Annex $\vee$ of the Habitats Directive). The remaining 29 wolves were killed south of Douro River, despite the legal mandate to designate special areas of conservation and strict species protection (Annexes II and IV of the EU's Habitats Directive, respectively; Fig. 1). Those wolves killed under Annexes II and IV were exceptions to article 12 of the Habitats Directive. Such exceptions are in principle connected to article 16, which allows member states to ask for them, 'provided that there is no satisfactory alternative and the derogation is not detrimental to the maintenance of the populations of the species and to its favourable conservation status in their natural range' (see also discussion in Rosen and Bath 2009). The Directive provides coverage for several types of exceptions; one of them was removing individuals 'to prevent serious damage, in particular to crops, livestock, forests, fisheries and water and other types of property'. The Directive however does not define 'serious damage' or 'satisfactory alternative'. Additionally, what could be detrimental to the favorable conservation status of concerned populations is debatable (Epstein et al. 2015; Trouwborst et al. 2016). Therefore, it remains 
subjective whether the response - killing wolves - is proportional to the predatory damage, and if it is actually a consequence of lacking proactive alternatives, like appropriate livestock husbandry. Here we seek to improve our understanding of biological aspects of the much quoted 'favorable conservation status', a guidance concept for member states to achieve the goals of the international agreement (Epstein et al. 2015), because those aspects were not fully considered when the term started appearing in environmental legislation. As it stands in the Habitats Directive, the favorable conservation status is clearly related to population viability and sustainability (e.g., definitions in Article 1; European Union 1992), hence we use it as reference to discuss implications of Spanish lethal management in the context of conservation biology.

\section{Numerical sustainability of lethal management}

Lethal management is often discussed in terms of numerical sustainability. A frequent albeit crude approach to the discussion focuses on the percentage of the wolf population taken each year. A $30 \%$ exploitation threshold has been often used as benchmark for numerical sustainability of wolf populations, but with a large uncertainty on that threshold (reviewed in Fuller et al. 2003; see also Adams et al. 2008). To apply that benchmark to the Iberian wolf population, we would need to know several population parameters that are just not available. Regarding population size, a recent Spanish estimate counted 297 wolf packs in the period 2012-2014 (MAGRAMA 2016), and about 55 additional packs were reported in Portugal (Torres and Fonseca 2016). Using rough estimates of the average number of wolves per pack, one could get values as disparate as 1400 or 3000 wolves in the Iberian population, using either winter (after dispersal and winter mortality) or summer (including pups) averages, respectively (e.g., Chapron et al. 2016). These figures suggest a relatively large population size in the European context. However, the associated uncertainty is very large, and an average harvest figure cannot be assumed to be representative of the whole Iberian area (Table 1). Some packs are rarely targeted, especially those that hold territories farther away from human interest, or in regions where socio-political pressure is low (Woodroffe 2000; Chapron and López-Bao 2014; Fernández-Gil et al. 2016), whereas packs at the border of the wolf range sustain harvest despite of tenuous wolf presence (Table 1). This variation has many effects, including pack size. In such situations, a framework considering sources and sinks would offer better insights into population dynamics and management implications, e.g., present management of wolves may affect the possibilities of range expansion, a topic further discussed below.

$$
\text { Beyond the } 30 \% \text { threshold mentioned above, it is still debated whether human-caused mortality rates in }
$$
wolves is additive, super-additive or, on the contrary, compensatory (Creel and Rotella 2010; Gude et al. 
2012). We suggest that a rough stability in population size may not be considered a valid indicator of sustainability, much less of favorable conservation status. Randomly distributed mortality may be compensated by high birth rates, but the effect of the population turnover on the social organization and behavior, e.g., ability to take down large wild prey, or on the gene flow and connectivity across the population, are difficult to assess. Whereas exploitation may depress the growth rate of wolf populations, should that be the goal, it should not occur at levels incompatible with the obligations of conservationoriented legislation.

Any management plan including conservation of a favorable population status as a goal needs to take into account that the reported number of wolf deaths are minimum numbers. There is high uncertainty around the number of accidental wolf deaths (Colino-Rabanal et al. 2011) and, specially, poaching. The number of cryptic deaths due to poaching can actually reach similar proportions as those of legally killed animals (Liberg et al. 2011; Suutarinen and Kojola 2017). Several studies have stressed recently that legal killing may not be the best approach to reduce illegal mortality of wolves (Chapron and Treves 2016; Suutarinen and Kojola 2018), or to solve livestock depredations (e.g. Treves et al. 2016). Although no legal wolf killing occurred in Portugal during the study period, no range expansion was detected, and a large level of illegal mortality is reported to be the driver of the dynamics (Torres and Fonseca 2016). Despite the potential importance of cryptic deaths, the lethal management policies we reviewed here were not based on estimates of whole mortality rates. Such a management scenario is at odds with Articles 11 and 14 of the Habitats Directive, which require that Member States monitor the conservation status of listed species.

\section{Intrapopulation differentiation and genetic status}

Individuals do not contribute equally to population growth rate or gene flow, and such population heterogeneity has to be considered in management (Bolnick et al. 2003; Alexander and Sanderson 2014), although it is not in Spain. Among other key components of population biology, the effective population size (Ne), the number of individuals that contribute to the reproduction every generation (Frankham 1995; Palstra and Fraser 2012), is particularly relevant to evaluate the viability of populations and the outcome of management policies (Shaffer 1981; Laikre et al. 2013; Frankham et al. 2014). The effective population size of Iberian wolves has been estimated, and at $\mathrm{Ne}<60$ it is much lower than any estimate of census population size, indicating that the population went through severe bottlenecks not too long ago (Sastre et al. 2011; Pilot et al. 2014; Gómez-Sánchez et al. 2018). 
Beyond considerations of population genetics in the evaluation of favorable conservation status, lethal wolf management, as implemented in Spain, does not target specific individuals. Therefore, it does not take into account issues like changes in selective forces (Darimont et al. 2009), social status or pack stability (Wallach et al. 2009; Borg et al. 2014), characteristics of the individuals (age, sex, physical condition etc.), or the source and bearing of killed individuals. Wolves are social animals that live in family groups, and younger individuals often disperse from their natal pack (Mech and Boitani 2003), sometimes traveling hundreds of kilometers before eventually settling into a new area (Vilà et al. 2003; Blanco and Cortés 2007; Andersen et al. 2015). As in many other vertebrate species, wolf dispersal can yield range expansion or recovery through settlement of young individuals, and genetic exchange through outbreeding of long-distance dispersers. However, unexpectedly high levels of genetic structure, compatible with lower than expected intra-population dispersal, have been recently reported in Iberian wolves (Silva et al. 2018). Dispersing wolves travel through unfamiliar terrain, and sometimes through already held wolf territories, which increases their risk of being hunted or culled (Mech and Boitani 2003; Schmidt et al. 2017). There is evidence that exploitation reduces local dispersal, emigration, and immigration of wolves, either as direct demographic compensation for human exploitation (Adams et al. 2008) or as a consequence of reduced intraspecific competition (Rick et al. 2017).

The recovery and favorable conservation status of wolf populations requires a proper functioning of dispersal. In the Iberian context, dispersal could alleviate the genetic consequences of past bottlenecks (Vilà et al. 2003; Sastre et al. 2011; Pilot et al. 2014; Gómez-Sánchez et al. 2018), providing genetic and demographic rescue to the endangered wolves in Portugal (Torres and Fonseca 2016), and reaching Spanish areas where they were recently extirpated or their presence is sporadic (Echegaray and Vilà 2010; López-Bao et al. 2015; Gómez-Sánchez et al. 2018). Elsewhere, dispersal is helping wolf recovery after historical decline and isolation (Fabbri et al. 2007). Arrival of wolves from the Alps to the eastern Pyrenees (Valière et al. 2003; Deinet et al. 2013; Louvrier et al. 2017) raised the possibility of recovering gene flow between Iberian and other European wolves. However, that possibility also depends on the arrival of Iberian wolves to the east of their present contiguous range, which, despite the size of the Iberian wolf population in a western European context, has not been documented (Hindrikson et al. 2017). Such gene flow, which does not necessarily involve many individuals (e.g. Fabbri et al. 2007), could have beneficial effects for the Iberian population after centuries of isolation (Sastre et al. 2011; Hindrikson et al. 2017). Dispersal from Iberia could also benefit inbred Italian wolves (Pilot et al. 2014; Hindrikson et al. 2017), and wolf recovery in France. In theory, dispersal to a species' former natural range is explicitly favored by the Habitats Directive, for example 
Articles 1i, 2 and 12 (see also Trouwborst et al. 2015), and is implicit in the inclusion of wolves in Annexes II and IV in the southern Iberian Peninsula.

\section{Transboundary management and isolation}

Although in biology it is clear that wildlife heeds no administrative boundaries, the human side of the conservation equation is indeed affected by those boundaries, sometimes creating a mindset that overrides the biological meaning of populations. The issue is increasingly recognized in the scientific literature (Rosen and Bath 2009; Trouwborst 2015; Thornton et al. 2018). Like other large carnivores, wolves in western Europe have a discontinuous range resulting from persecution and habitat loss in recent centuries (Fig. 1B). The contraction resulted in the relatively small and genetically differentiated Iberian and Alpine / Italian populations (Pilot et al. 2014). They have been isolated for a long time from other populations, making them particularly good candidates to provide and receive demographic and genetic rescue with other populations (e.g., Hindrikson et al. 2017). Isolation from other wolf populations is therefore a relevant aspect to consider when evaluating lethal management of Iberian wolves, and the same applies to other populations (Kojola et al. 2009). The scenario is not comparable for those populations used to study numerical sustainability of human exploitation of wolves in North America, or even in specific parts of Europe (Śmietana and Wajda 1997). The wolf population in eastern Europe is at the edge of the large and less fragmented wolf range towards the Eastern Palearctic (Figure 1B), a situation reflected in the higher genetic diversity of those wolves (Hindrikson et al. 2017). The existence of larger, relatively contiguous wolf range alongside areas where wolves sustain lethal measures may drive a management scenario of source-sink dynamics (Novaro et al. 2005), which at least ought to be considered if discussing numerical sustainability of lethal management within given administrative boundaries. A local population subject to lethal management might appear sustainable if a neighboring one acts as source of incoming individuals (see also Schmidt et al. 2017).

Most European wolf populations are transboundary (Figure 1B). The Iberian population is shared by Portugal and Spain; the Alpine-Italian population, by Italy, France, and Switzerland (Fabbri et al. 2007). Norwegian wolves are just a little part of the Scandinavian wolf population (Svensson et al. 2015; Hindrikson et al. 2017), which in turn has partially recovered after the arrival of long-distance dispersers from eastern Europe (Vilà et al. 2003). Further south, the eastern European wolf population extends over lands belonging to more than twelve countries. Any of those countries could use a different approach to wolf management, which would affect not only the wolves that live or traverse their own lands, but the whole shared population. 
301

The wolves of the Białowieża Primeval Forest, for example, span the Poland-Belarus border, and sustain heavy hunting on the Belarussian side (Jedrzejewski et al. 2005). As mentioned above, the Iberian population is strictly protected in Portugal since 1988, yet it is subject to culling and hunting just across the border in Spain (Figure 1A; Table 1). Italy does not use lethal management, but France recently programmed annual culling on its portion of the shared population (Ministère de la Transition Écologique et Solidaire 2018). This decision could compromise the incipient genetic flux within, towards, and from the population, including the potential contact with the Iberian population (Valière et al. 2003; Louvrier et al. 2017). Even in the larger Eastern-Central wolf population, lethal management of wolves in Slovakia appears to affect their conservation status across the border in the Czech Republic (Kutal et al. 2016). These transboundary problems are not exclusive of wolves but occur at least in other populations of large carnivores. In Scandinavia, for instance, Sweden is a source and Norway a sink for the wolverine population (Gervasi et al. 2015), and the eventual recovery of brown bears in Norway depends on the arrival of bears from Sweden (Gilroy et al. 2015). Despite the clear transboundary nature of populations of large carnivores (Linnell et al. 2008), the European Union and its legislative instrument the Habitats Directive led to management and conservation plans at a national level (Rosen and Bath 2009).

The discussion about transboundary populations seems easier to comprehend, and it is certainly easier to document, at the country level. However, it applies also at the sub-national level. The administrative framework of the Iberian wolf population includes two countries that are member-states of the European Union, and 17 regions in Spain that retain management authority (Table 1). Eight of those regions had wolves in the most recent count of packs (MAGRAMA 2016). The fragmented management of Iberian wolves actually results in uneven adherence to the obligations of the EU Habitats Directive, which are followed closely by some regions, loosely by others, or disregarded completely by other regions that conducted "population control" campaigns despite of minimal wolf presence (Table 1; Fig. 1A). Lethal management in the latter case is especially at odds with article 15 of the Habitats Directive, which required that member states 'shall prohibit the use of all indiscriminate means [of population control] capable of causing local disappearance of, or serious disturbance to, populations'. Another remarkable circumstance is that regional administrations are responsible for the establishment and implementation of lethal management measures, but are not accountable to international agreements, including the Bern Convention and the Habitats Directive, subscribed by the national government. The fragmentation of management strategies could result in regions or states ignoring conservation agendas and implementing aggressive actions, while assuming 
331

that those would have only minor effects on the total population. Thus, the survival of local populations would depend on the conservation programs in neighboring countries and regions being sufficient to provide dispersers to fill those population sinks.

Administrative fragmentation of wolf management may occur in other European countries, especially those where regional governments hold management responsibilities. That could be the case for instance in Austria, where federal states have the hunting and conservation authority (Schäfer 2012), or Germany, where authority is similarly or even further decentralized (Kaczensky et al. 2012). In addition, several countries where wolf management is in principle centralized still show fragmentation. In Italy, regional administrations vary widely in handling compensation to depredations, irrespective of wolf abundance (Boitani et al. 2010). In Serbia, management is also fragmented, even distinguishing between wolf males and females or pups (Kaczensky et al. 2012). Finland discriminates wolf management in its reindeer zone, where lethal management is more intense (Kaczensky et al. 2012; Trouwborst 2014b). In addition, the EU Habitats Directive splits wolf management in Greece along the $39^{\circ} \mathrm{N}$ parallel, placing wolves in the south in Annex IV (strict protection), and wolves in the north in Annex $\mathrm{V}$ (may be subject to management).

\section{Other plausible factors limiting range recovery}

Besides lethal management, there could be additional determinants of the apparent lack of range recovery of wolves in the Iberian Peninsula. For instance, recovery may be hampered if areas outside the current range had become too human-dominated, beyond the ability of wolves to traverse or settle. The Iberian Peninsula has an average human density of about 100 people $/ \mathrm{km}^{2}$, and it is crisscrossed by numerous linear and often fenced infrastructures (Blanco and Cortés 2007; Rodríguez-Freire and CrecenteMaseda 2008). However, human population has been declining in the regions where conflict with predators is most frequent (MARM 2009). In addition, not all landscapes are equally human-dominated. The Iberian Peninsula contains extensive areas outside the present wolf range where human appropriation of primary production (Haberl et al. 2007) is presently comparable to that of areas used by wolves. Habitat suitability analyses recently reported that substantial habitat exists outside the present wolf range, both at a fine spatial scale that would reflect suitability as breeding habitat, and at coarser spatial scales that would indicate presence and traversing suitability (Grilo et al. 2018). In addition to overall habitat availability, an important fraction of wolves' former range in Iberia includes areas listed as candidates to the Natura 2000 network of protected areas (European Environment Agency 2018), especially south of the Douro River and in the central part of the Iberian Peninsula. These sites may provide important stepping stones for wolves dispersing 
across more developed landscapes, and seem like an appropriate target for Spain and Portugal to meet the requirements of Annex II of the Habitats Directive, 'the designation of special areas of conservation', for those species listed in them. Additionally, the recovery of wild ungulate populations is evident in the Iberian Peninsula, even in agricultural landscapes (e.g., Apollonio et al. 2010), so the availability of wild prey should facilitate the colonization of new areas by wolves without major conflict with human interests. The present combination of available habitat and productivity suggest that the return and settlement of wolves to historical reaches of their range is ecologically feasible. Recent models based on niche analyses, and current and historical distributions of large carnivores in Europe arrived at similar conclusions (Milanesi et al. 2017).

Obviously, the difficulties for range recovery of a large carnivore in the Iberian Peninsula and beyond should not be oversimplified. Despite the protective EU legislation and availability of habitats and prey, a complex mixture of factors is probably behind the difficulties of wolves to effectively disperse out of the present contiguous range. Private land ownership and pressures from special-interest lobbies may undermine an otherwise valid legislation, and certainly complicate management (López-Bao et al. 2015). In addition, dispersing wolves likely have a higher mortality rate due to intraspecific strife, accidents or poaching, as discussed above, and may show habitat-biased dispersal (Pilot et al. 2006; Leonard 2014). Nevertheless, while removing physical and societal barriers to animal movements and alleviating the human footprint are complicated tasks on the short term, reducing lethal management pressure in Spain seems a feasible policy change. This single change could improve the connectivity and thus the conservation status of the Iberian wolf population.

\section{Conclusions}

Multiple facets may be considered to address the implications of lethal management of wolves as implemented in the Iberian Peninsula. However, besides discussing some of those facets, we remain aware of the management mindset (e.g., Ludwig 2001), which seems to center discussions on quotas of exploitation. Removing individuals from wild populations of large carnivores is certainly not mandatory, regardless of the outcome of discussions on its numerical sustainability (Artelle et al. 2013; see also Darimont 2017). Lethal management is instead a policy option, which seems particularly debatable in the case of apex predators (Ordiz et al. 2013; Wallach et al. 2015), often implemented to reduce conflicts (Fernández-Gil et al. 2016; Chapron and Treves 2016; Treves et al. 2016), under the premise of maintaining a favorable conservation status. The goal of conservation biology is not merely keeping a vague notion of enough animals, or the presence of species in a territory, but a functional assemblage of species (e.g., Soulé 
391

1985). Managing towards that goal requires incorporation of the full range of ecological characteristics of the populations. Consider for instance how clear it is today that migration corridors and wintering grounds are crucial for bird conservation (e.g., Donald et al. 2007). In the case of wolves, a social structure based on family relations and a tendency for long-distance dispersal are similarly key characteristics, disturbed by hunting and culling. European wolf populations have increased in the last 30 years, both in numbers and range; however, despite its relatively large size, the wolf population in the Iberian Peninsula has remained isolated. Concurrently, the Sierra Morena wolves may have been extirpated, after showing high levels of inbreeding and introgression with dogs (Gómez-Sánchez et al. 2018). Yet we are not aware of effective efforts to coordinate conservation plans across countries, or regions.

\section{Compliance with Ethical Standards}

The authors declare that they have no conflict of interest. This study did not involve any experimentation or handling of human or animal subjects. The consent to submit the manuscript has been received explicitly from all co-authors. We all have consent from the authorities at our respective organizations to conduct this research, and to submit it for publication.

\section{References}

Adams LG, Stephenson RO, Dale BW, et al (2008) Population Dynamics and Harvest Characteristics of Wolves in the Central Brooks Range, Alaska. Wildl Monogr 1-25. https://doi.org/10.2193/2008-012

Alexander KA, Sanderson CE (2014) Conserving Carnivores: More than Numbers. Science 343:1199-1199. https://doi.org/10.1126/science.343.6176.1199-a

Andersen LW, Harms V, Caniglia R, et al (2015) Long-distance dispersal of a wolf, Canis lupus, in northwestern Europe. Mammal Res 60:163-168. https://doi.org/10.1007/s13364-015-0220-6

Apollonio M, Andersen R, Putman R (2010) European ungulates and their management in the 21st century. Cambridge University Press.

Artelle KA, Anderson SC, Cooper AB, et al (2013) Confronting Uncertainty in Wildlife Management: Performance of Grizzly Bear Management. PLOS ONE 8:e78041. https://doi.org/10.1371/journal.pone.0078041

Blanco JC, Cortés Y (2007) Dispersal patterns, social structure and mortality of wolves living in agricultural habitats in Spain. J Zool 273:114-124. https://doi.org/10.1111/j.1469-7998.2007.00305.x

Blanco JC, Cortés Y (2012) Surveying wolves without snow: a critical review of the methods used in Spain. 
Hystrix, the Italian Journal of Mammalogy 23:35-48. https://doi.org/10.4404/hystrix-23.1-4670

421

Blanco JC, Reig S, de la Cuesta L (1992) Distribution, status and conservation problems of the wolf Canis lupus in Spain. Biol Conserv 60:73-80. https://doi.org/10.1016/0006-3207(92)91157-N

Boitani L, Ciucci P, Raganella-Pelliccioni E (2010) Ex-post compensation payments for wolf predation on livestock in Italy: a tool for conservation? Wildl Res 37:722-730. https://doi.org/10.1071/WR10029

Bolnick DI, Svanbäck R, Fordyce JA, et al (2003) The ecology of individuals: incidence and implications of individual specialization. Am Nat 161:1-28. https://doi.org/10.1086/343878

Borg BL, Brainerd SM, Meier TJ, Prugh LR (2014) Impacts of breeder loss on social structure, reproduction and population growth in a social canid. J Anim Ecol 84:177-187. https://doi.org/10.1111/13652656.12256

Breitenmoser U (1998) Large predators in the Alps: The fall and rise of man's competitors. Biol Conserv 83:279-289. https://doi.org/10.1016/S0006-3207(97)00084-0

Chapron G, Kaczensky P, Linnell JDC, et al (2014a) Recovery of large carnivores in Europe's modern human-dominated landscapes. Science 346:1517-1519. https://doi.org/10.1126/science.1257553

Chapron G, Kaczensky, Petra, Linnell, John D. C., et al (2014b) Data from: Recovery of large carnivores in Europe's modern human-dominated landscapes. Dryad Digital Repository https://doi.org/10.5061/dryad.986mp

Chapron G, López-Bao JV (2014) Conserving Carnivores: Politics in Play. Science 343:1199-1200. https://doi.org/10.1126/science.343.6176.1199-b

Chapron G, Treves A (2016) Blood does not buy goodwill: allowing culling increases poaching of a large carnivore. Proc R Soc B 283:20152939. https://doi.org/10.1098/rspb.2015.2939

Chapron G, Wikenros C, Liberg O, et al (2016) Estimating wolf (Canis lupus) population size from number of packs and an individual based model. Ecol Model 339:33-44. https://doi.org/10.1016/j.ecolmodel.2016.08.012

Colino-Rabanal VJ, Lizana M, Peris SJ (2011) Factors influencing wolf Canis lupus roadkills in Northwest Spain. Eur J Wildl Res 57:399-409. https://doi.org/10.1007/s10344-010-0446-1

Council of Europe (1979) Convention on the Conservation of European Wildlife and Natural Habitats (Bern Convention). https://www.coe.int/en/web/bern-convention. Accessed 11 November 2018

Creel S, Rotella JJ (2010) Meta-Analysis of Relationships between Human Offtake, Total Mortality and 
Population Dynamics of Gray Wolves (Canis lupus). PLOS ONE 5:e12918. https://doi.org/10.1371/journal.pone.0012918

Darimont CT (2017) Trophy hunting: Science on its own can't dictate policy. Nature 551:565. https://doi.org/10.1038/d41586-017-07553-6

Darimont CT, Carlson SM, Kinnison MT, et al (2009) Human predators outpace other agents of trait change in the wild. Proc Natl Acad Sci 106:952-954. https://doi.org/10.1073/pnas.0809235106

Deinet S, leronymidou C, McRae L, et al (2013) Wildlife comeback in Europe: The recovery of selected mammal and bird species. Final report to Rewilding Europe. ZSL, BirdLife International and the European Bird Census Council, London

Donald PF, Sanderson FJ, Burfield IJ, et al (2007) International Conservation Policy Delivers Benefits for Birds in Europe. Science 317:810-813. https://doi.org/10.1126/science.1146002

Echegaray J, Vilà C (2010) Noninvasive monitoring of wolves at the edge of their distribution and the cost of their conservation. Anim Conserv 13:157-161. https://doi.org/10.1111/j.1469-1795.2009.00315.x

Epstein Y, López-Bao JV, Chapron G (2015) A Legal-Ecological Understanding of Favorable Conservation Status for Species in Europe. Conserv Lett 9:81-88. https://doi.org/10.1111/conl.12200

Estes JA, Terborgh J, Brashares JS, et al (2011) Trophic Downgrading of Planet Earth. Science 333:301306. https://doi.org/10.1126/science.1205106

European Environment Agency (EEA) (2018) Natura 2000 data - the European network of protected sites. https://www.eea.europa.eu/data-and-maps/data/natura-9. Accessed 11 November 2018

European Union (1992) Council Directive 92/43/EEC of 21 May 1992 on the conservation of natural habitats and of wild fauna and flora. https://eur-lex.europa.eu/legal-content/EN/TXT/?uri=CELEX:01992L004320070101. Accessed 11 November 2018

Fabbri E, Miquel C, Lucchini V, et al (2007) From the Apennines to the Alps: colonization genetics of the naturally expanding Italian wolf (Canis lupus) population. Mol Ecol 16:1661-1671.

$$
\text { https://doi.org/10.1111/j.1365-294X.2007.03262.x }
$$

Fernández-Gil A, Naves J, Ordiz A, et al (2016) Conflict misleads large carnivore management and conservation: Brown bears and wolves in Spain. PLOS ONE 11:e0151541.

$$
\text { https://doi.org/10.1371/journal.pone.0151541 }
$$

Frankham R (1995) Effective population size/adult population size ratios in wildlife: A review. Genet Res 
Frankham R, Bradshaw CJA, Brook BW (2014) Genetics in conservation management: Revised recommendations for the 50/500 rules, Red List criteria and population viability analyses. Biol Conserv 170:56-63. https://doi.org/10.1016/j.biocon.2013.12.036

Fuller T, Mech L, Cochrane J (2003) Wolf population dynamics. In: Mech L, Boitani L (eds) Wolves: behavior, ecology, and conservation. University of Chicago Press, pp 131-160

Galaverni M, Caniglia R, Fabbri E, et al (2016) One, no one, or one hundred thousand: how many wolves are there currently in Italy? Mammal Res 61:13-24. https://doi.org/10.1007/s13364-015-0247-8

Gervasi V, Brøseth H, Nilsen EB, et al (2015) Compensatory immigration counteracts contrasting conservation strategies of wolverines (Gulo gulo) within Scandinavia. Biol Conserv 191:632-639. https://doi.org/10.1016/j.biocon.2015.07.024

Gilroy JJ, Ordiz A, Bischof R (2015) Carnivore coexistence: Value the wilderness. Science 347:382-382. https://doi.org/10.1126/science.347.6220.382-a

Gippoliti S, Brito D, Cerfolli F, et al (2018) Europe as a model for large carnivores conservation: Is the glass half empty or half full? J Nat Conserv 41:73-78. https://doi.org/10.1016/j.jnc.2017.11.007

Gómez-Sánchez D, Olalde I, Sastre N, et al (2018) On the path to extinction: Inbreeding and admixture in a declining grey wolf population. Mol Ecol 27:3599-3612. https://doi.org/10.1111/mec.14824

Grilo C, Lucas PM, Fernández-Gil A, et al (2018) Refuge as major habitat driver for wolf presence in humanmodified landscapes. Anim Conserv. https://doi.org/10.1111/acv.12435

Gude JA, Mitchell MS, Russell RE, et al (2012) Wolf population dynamics in the U.S. Northern Rocky Mountains are affected by recruitment and human-caused mortality. J Wildl Manag 76:108-118. https://doi.org/10.1002/jwmg.201

Haberl H, Erb KH, Krausmann F, et al (2007) Quantifying and mapping the human appropriation of net primary production in earth's terrestrial ecosystems. Proc Natl Acad Sci 104:12942-12947. https://doi.org/10.1073/pnas.0704243104

Hindrikson M, Remm J, Pilot M, et al (2017) Wolf population genetics in Europe: a systematic review, metaanalysis and suggestions for conservation and management. Biol Rev 92: 1601-1629. https://doi.org/10.1111/brv.12298 Jedrzejewski W, Branicki W, Veit C, et al (2005) Genetic diversity and relatedness within packs in an 
intensely hunted population of wolves Canis lupus. Acta Theriol (Warsz) 50:3-22. https://doi.org/10.1007/BF03192614

Kaczensky P, Chapron G, Von Arx M, et al (2012) Status, management and distribution of large carnivoresbear, lynx, wolf \& wolverine-in Europe. Report by LCIE for the European Commission.

Kojola I, Kaartinen S, Hakala A, et al (2009) Dispersal Behavior and the Connectivity Between Wolf Populations in Northern Europe. J Wildl Manag 73:309-313. https://doi.org/10.2193/2007-539

Kutal M, Váňa M, Suchomel J, et al (2016) Trans-Boundary Edge Effects in the Western Carpathians: The Influence of Hunting on Large Carnivore Occupancy. PLOS ONE 11:e0168292. https://doi.org/10.1371/journal.pone.0168292

Laikre L, Jansson M, Allendorf FW, et al (2013) Hunting Effects on Favourable Conservation Status of Highly Inbred Swedish Wolves: Hunting and Swedish Wolves. Conserv Biol 27:248-253. https://doi.org/10.1111/j.1523-1739.2012.01965.x

Leonard JA (2014) Ecology drives evolution in grey wolves. Evol Ecol Res 16:461-473.

Leonard JA, Vilà C, Wayne RK (2005) Legacy lost: genetic variability and population size of extirpated US grey wolves. Mol Ecol 14:9-17. https://doi.org/10.1111/j.1365-294X.2004.02389.x

Liberg O, Chapron G, Wabakken P, et al (2011) Shoot, shovel and shut up: cryptic poaching slows restoration of a large carnivore in Europe. Proc R Soc B Biol Sci rspb20111275. https://doi.org/10.1098/rspb.2011.1275

Linnell J, Salvatori V, Boitani L (2008) Guidelines for population level management plans for large carnivores in Europe. A Large Carnivore Initiative for Europe report prepared for the European Commission (contract 070501/2005/424162/MAR/B2).

López-Bao JV, Blanco JC, Rodríguez A, et al (2015) Toothless wildlife protection laws. Biodivers Conserv 14. https://doi.org/10.1007/s10531-015-0914-8

Louvrier J, Duchamp C, Lauret V, et al (2017) Mapping and explaining wolf recolonization in France using dynamic occupancy models and opportunistic data. Ecography 41:647-660. https://doi.org/10.1111/ecog.02874

Ludwig D (2001) The Era of Management Is Over. Ecosystems V4:758-764. https://doi.org/10.1007/s10021$\underline{001-0044-x}$

MAGRAMA (2016) Censo 2012-2014 de lobo ibérico (Canis lupus, Linnaeus, 1758) en España. Ministerio de 
Agricultura, Alimentación y Medio Ambiente, Madrid.

https://www.miteco.gob.es/en/biodiversidad/temas/inventarios-

nacionales/censo_lobo_espana_2012_14pdf_tcm38-197304.pdf. Accessed 11 November 2018

MARM (2009) Población y Sociedad Rural. Análisis y Prospectiva. Serie Agrlnfo 12. Subdirección General de Análisis, Prospectiva y Coordinación, Subsecretaría. Ministerio de Medio Ambiente y Medio Rural y Marino. NIPO: 770-09-195-9

Mech LD, Boitani L, (IUCN SSC Wolf Specialist Group) (2010) Canis lupus. The IUCN Red List of Threatened Species 2010: e.T3746A10049204. http://doi.org/10.2305/IUCN.UK.20104.RLTS.T3746A10049204.en

Mech LD, Boitani L (2003) Wolf social ecology. In: Mech LD, Boitani L (eds) Wolves: behavior, ecology, and conservation. University of Chicago Press, pp 1-34

Mech LD, Peterson RO (2003) Wolf-prey relations. In: Mech LD, Boitani L (eds) Wolves: behavior, ecology, and conservation. University of Chicago Press, pp 131-160

Milanesi P, Breiner FT, Puopolo F, Holderegger R (2017) European human-dominated landscapes provide ample space for the recolonization of large carnivore populations under future land change scenarios. Ecography 40:1359-1368. https://doi.org/10.1111/ecog.02223

Ministère de la Transition Écologique et Solidaire (2018) Plan national d'actions 2018-2023 sur le loup et les activités d'élevage. https://www.ecologique-solidaire.gouv.fr/plan-national-dactions-2018-2023-sur-loupet-activites-delevage. Accessed 11 November 2018

Novaro AJ, Funes MC, Walker RS (2005) An empirical test of source-sink dynamics induced by hunting. J Appl Ecol 42:910-920. https://doi.org/10.1111/j.1365-2664.2005.01067.x

Ordiz A, Bischof R, Swenson JE (2013) Saving large carnivores, but losing the apex predator? Biol Conserv 168:128-133. https://doi.org/10.1016/j.biocon.2013.09.024

Padial JM, Contreras FJ, Pérez J, et al (2000) Análisis de la situación y problemática del lobo (Canis lupus signatus) en Sierra Morena oriental (sur de España). Galemys 12:37-44.

Palomo LJ, Gisbert J, Blanco J (2007) Atlas y libro Rojo de los mamiferos terrestres de España. Organismo Autónomo Parques Nacionales, Madrid. https://www.miteco.gob.es/es/biodiversidad/temas/inventariosnacionales/inventario-especies-terrestres/inventario-nacional-de-biodiversidad/ieet_mamif_atlas.aspx. Accessed 11 November 2018 
Palstra FP, Fraser DJ (2012) Effective / census population size ratio estimation: a compendium and appraisal. Ecol Evol 2:2357-2365. https://doi.org/10.1002/ece3.329

Petrucci-Fonseca F (1990) O lobo (Canis lupus signatus Cabrera, 1907) em Portugal. Problemática da sua conservação. PhD Thesis, Universidade de Lisboa

Pilot M, Greco C, vonHoldt BM, et al (2014) Genome-wide signatures of population bottlenecks and diversifying selection in European wolves. Heredity 112:428-442. https://doi.org/10.1038/hdy.2013.122

Pilot M, Jedrzejewski W, Branicki W, et al (2006) Ecological factors influence population genetic structure of European grey wolves. Mol Ecol 15:4533-4553. https://doi.org/10.1111/j.1365-294X.2006.03110.x

Rick JA, Moen RA, Erb JD, Strasburg JL (2017) Population structure and gene flow in a newly harvested gray wolf (Canis lupus) population. Conserv Genet 18: 1091-1104. https://doi.org/10.1007/s10592-0170961-7

Rico M, Torrente JP (2000) Caza y rarificación del lobo en España: investigación histórica y conclusiones biológicas. Galemys 12:163-179. http://www.secem.es/wp-content/uploads/2013/03/G-12-NE-14-Rico163-179.pdf. Accessed 11 November 2018

Rodríguez-Freire M, Crecente-Maseda R (2008) Directional Connectivity of Wolf (Canis lupus) Populations in Northwest Spain and Anthropogenic Effects on Dispersal Patterns. Environ Model Assess 13:35. https://doi.org/10.1007/s10666-006-9078-y

Rosen T, Bath A (2009) Transboundary management of large carnivores in Europe: from incident to opportunity. Conserv Lett 2:109-114. doi: 10.1111/j.1755-263X.2009.00054.x

Sastre N, Vilà C, Salinas M, et al (2011) Signatures of demographic bottlenecks in European wolf populations. Conserv Genet 12:701-712. https://doi.org/10.1007/s10592-010-0177-6

Schäfer M (2012) The National Wolf Strategy in Austria: An Evaluation of the Wolf Management-Plan and its Formulation Process using the Multiple-Streams Framework. Master's Thesis, Swiss Federal Institute of Technology Zurich

Schmidt JH, Burch JW, MacCluskie MC (2017) Effects of control on the dynamics of an adjacent protected wolf population in interior Alaska: Population Dynamics of Wolves in Interior Alaska. Wildl Monogr 198:130. https://doi.org/10.1002/wmon.1026

Shaffer ML (1981) Minimum Population Sizes for Species Conservation. Bioscience 31:131-134. https://doi.org/10.2307/1308256 
Silva P, López-Bao JV, Llaneza L, et al (2018) Cryptic population structure reveals low dispersal in Iberian wolves. Sci Rep 8:14108. https://doi.org/10.1038/s41598-018-32369-3

Śmietana W, Wajda J (1997) Wolf number changes in Bieszczady National Park, Poland. Acta Theriol (Warsz) 42:241-252. https://doi.org/10.4098/AT.arch.97-26

Soulé ME (1985) What is conservation biology? BioScience 35:727-734. https://doi.org/10.2307/1310054

Suutarinen J, Kojola I (2018) One way or another: predictors of wolf poaching in a legally harvested wolf population. Anim Conserv. https://doi.org/10.1111/acv.12409

Suutarinen J, Kojola I (2017) Poaching regulates the legally hunted wolf population in Finland. Biol Conserv 215:11-18. https://doi.org/10.1016/j.biocon.2017.08.031

Svensson L, Wabakken P, Maartmann E, et al (2015) Inventering av varg vintern 2014-15. Rovdata och Viltskadecenter, SLU

Thornton DH, Wirsing AJ, Lopez-Gonzalez C, et al (2018) Asymmetric cross-border protection of peripheral transboundary species. Conserv Lett 11:e12430. https://doi.org/10.1111/conl.12430

Torres RT, Fonseca C (2016) Perspectives on the Iberian wolf in Portugal: population trends and conservation threats. Biodivers Conserv 25:411-425. https://doi.org/10.1007/s10531-016-1061-6

Treves A, Krofel M, McManus J (2016) Predator control should not be a shot in the dark. Front Ecol Environ 14:380-388. https://doi.org/10.1002/fee.1312

Trouwborst A (2014a) The EU Habitats Directive and wolf conservation and management on the Iberian Peninsula: a legal perspective. Galemys 26. https://doi.org/10.7325/Galemys.2014.A2

Trouwborst A (2014b) Living with Success - And with Wolves: Addressing the Legal Issues Raised by the Unexpected Homecoming of a Controversial Carnivore. Eur Energy Environ Law Rev 23:89-101.

Trouwborst A (2015) Global large carnivore conservation and international law. Biodivers Conserv 24:15671588. https://doi.org/10.1007/s10531-015-0894-8

Trouwborst A, Boitani L, Linnell JDC (2016) Interpreting 'favourable conservation status' for large carnivores in Europe: how many are needed and how many are wanted? Biodivers Conserv 1-25. https://doi.org/10.1007/s10531-016-1238-z

Trouwborst A, Krofel M, Linnell JDC (2015) Legal implications of range expansions in a terrestrial carnivore: the case of the golden jackal (Canis aureus) in Europe. Biodivers Conserv 24:2593-2610. https://doi.org/10.1007/s10531-015-0948-y 
623

624

625

626

627

628

629

630

631

632

633

634

635

636

Valière N, Fumagalli L, Gielly L, et al (2003) Long-distance wolf recolonization of France and Switzerland inferred from non-invasive genetic sampling over a period of 10 years. Anim Conserv 6:83-92. https://doi.org/10.1017/S1367943003003111

Vilà C, Sundqvist A, Flagstad O, et al (2003) Rescue of a severely bottlenecked wolf (Canis lupus) population by a single immigrant. Proc R Soc Lond Ser B 270:91-97. https://doi.org/10.1098/rspb.2002.2184

Wagner C, Holzapfel M, Kluth G, et al (2012) Wolf (Canis lupus) feeding habits during the first eight years of its occurrence in Germany. Mamm Biol 77:196-203. https://doi.org/10.1016/j.mambio.2011.12.004

Wallach AD, Izhaki I, Toms JD, et al (2015) What is an apex predator? Oikos 124:1453-1461.

$$
\text { https://doi.org/10.1111/oik.01977 }
$$

Wallach AD, Ritchie EG, Read J, O'Neill AJ (2009) More than Mere Numbers: The Impact of Lethal Control on the Social Stability of a Top-Order Predator. PLoS ONE 4:e6861. https://doi.org/10.1371/journal.pone.0006861

Woodroffe R (2000) Predators and people: using human densities to interpret declines of large carnivores. Anim Conserv 3:165-173. https://doi.org/10.1111/j.1469-1795.2000.tb00241.x 
Table 1. Wolf management in the Iberian Peninsula. ${ }^{1}$ Wolf range $\left(\mathrm{km}^{2}\right)$ estimated from recent distribution maps (Chapron et al 2014b). ${ }^{2}$ Number of packs (Spain: MAGRAMA 2016; Portugal: Torres \& Fonseca 2016). 30 packs were counted twice, if they were shared between neighboring regions. ${ }^{3} \mathrm{Number}$ of wolves legally killed 2008-2013. ${ }^{4}$ Annexes of EU's Habitats Directive that apply in the Iberian Peninsula. ${ }^{5}$ Reference to the official management plan or conservation normative in force in 2008-2013.

\section{Region}

Galicia

Asturias

Cantabria

La Rioja

Euskadi

Castilla y León

\footnotetext{
Castilla-La Mancha

Madrid

Andalucía
}

Portugal

\section{Province / sector}

Wolf range

Lugo
Ourense
Pontevedra
A Coruña

$$
9,285
$$$$
7,093
$$$$
2,836
$$$$
5,084
$$

1,973

382

Bizkaia

Araba

León

Palencia

Burgos

Valladolid

Zamora

Soria

Ávila

Segovia

Salamanca

Guadalajara

North of Douro

South of Douro

$$
757
$$$$
14,632
$$$$
7,505
$$$$
12,062
$$$$
6,391
$$$$
9,674
$$

5,325

303

1,185

298

796

12,608

4,137

\section{Packs $^{2}$}

$\begin{array}{ccc}37 & 7 & \vee \\ 26 & 4 & \\ 11 & 1 & \\ 20 & 8 & \\ 37 & 108 & \\ 12 & 102 & \\ 1 & 5 & V\end{array}$

0

$297 / 2008$

$155 / 2002$

-

-

33 / 2010

1

137

68

20

9

132

0

7

7

6

0

0

-

Plan $^{5}$

\section{Lethal management}

$$
\begin{aligned}
& \text { culling + hunting } \\
& \text { culling + hunting } \\
& \text { culling + hunting } \\
& \text { culling + hunting } \\
& \text { culling } \\
& \text { culling + hunting } \\
& \text { culling + hunting } \\
& \text { culling + hunting } \\
& \text { culling } \\
& \text { culling + hunting } \\
& \text { culling + hunting } \\
& \text { culling + hunting } \\
& \text { culling + hunting } \\
& \text { culling + hunting } \\
& \text { hunting } \\
& \text { culling } \\
& \text { culling } \\
& \text { culling }
\end{aligned}
$$


644 The map shows the administrative units in Spain and Portugal. Shading indicates wolf range in the 645 Iberian Peninsula and southern France; lighter shading indicates sporadic presence (modified from Chapron et al. 2014b; Chapron et al. 2014a). Numbers inside Spanish provinces indicate grey wolves legally killed in

647 2008-2013. The map is divided in sectors of wolf protection under EU's Habitats Directive, following the 648 analysis by Trouwborst (2014a). Dashed lines and text in italics indicate sectors under unclear status in the 649 Habitats Directive. The solid blue line marks the Douro River, which in Spain separates lands where wolves 650 are listed in Annex V of the Directive to the north, and in Annexes II and IV to the south. In Portugal, wolves 651 are listed in Annexes II and IV.

Figure 1B. Grey wolf distribution in western Eurasia.

653 Shaded areas show the western part of the range of grey wolves in Eurasia. We used the permanent and 654 sporadic distributions datasets from Chapron et al. (2014b) for EU countries, complemented with the IUCN 655 Red List distribution map (Mech and Boitani 2010) for neighboring countries not covered in the former layer 656 (paler shading; note that latter dataset uses coarser spatial resolution). 
